\title{
Lung Cancer: Preventable Disease
}

\author{
Gordan Srkalović \\ Herbert-Herman Cancer Center, Sparrow \\ Hospital System, Lansing, MI, USA \\ Correspondence: \\ gordan.srkalovic@sparrow.org \\ Tel.: + 15173642182 \\ Fax.: + 15173642886
}

Received: 5 October 2017

Accepted: 31 May 2018

Key words: Lung Cancer - Cigarettes • Tobacco epidemics.
Objective of the paper is to present lung cancer as preventable disease based on epidemiological, molecular and genomic data. Lung cancer is the most deadly malignancy around the world, both in male and female population. Vast majority of lung cancers (close to 90\%) are directly caused by cigarette smoking, and thus present one of the most preventable deadly disease in humanity. Analysis of history of cigarette consumption and rise of lung cancer as world epidemics. Review of efforts to fight tobacco epidemics and how it influences incidence and prevalence of the lung cancer. Investigation of the effects of cigarette smoking on health and economic status of Bosnia and Hercegovina. Tobacco epidemics and lung cancer can be prevented. Goal is to exterminate cigarette smoking. That can be achieved only concerted effort by members of family, patients themselves, physicians, researchers, non-governmental organizations, political figures and society as a whole. Conclusion. In country like Bosnia and Herzegovina first step is to inform society about devastating effects of cigarette smoking. Best practices already exist and initial goal should be to start using them.

\section{Introduction}

Tobacco use presents the largest preventable cause of death and disability in developed and more and more in developing countries. It caused 100 million deaths in $20^{\text {th }}$ century and if current trend continues it will cause up to 1 billion deaths in $21^{\text {st }}$ century. It is responsible for $30 \%$ of all cancer deaths and $80 \%$ of lung cancer deaths and is associated with increased risk for at least 17 types of cancer (1). Very clear scientific evidence of causality between tobacco smoking and lung cancer was present since 1950's pioneering work by Wynder and Graham (2) as well as Doll and Hill (3). However it took 10 years for information to penetrate into public domain after 1964 Surgeon General's Report in which cancers of the lung and larynx in men (not women) were casually linked to cigarette smoking (4). The topic of smoking was then again addressed in the 1990 Surgeon General's Report on smoking cessation (1990) and in 1982 report which focused on cancer. In 2001 first report on women and smoking was published (USDHHS 2001) (4). Ultimately, report by Office of the Surgeon General (US): Office on Smoking and Health (US) published in 2004 clearly informed general public about lethal risks of cigarettes smoking and particularly emphasized advantage of smoking cessation based on Surveillance, Epidemiology and End Results (SEERS) data showing decline in rates of cancer from 1991 which coincided with decline in smoking among men and less by women (4). However, despite of all these efforts, lung cancer is still leading cause of cancer related deaths both in men and women. Estimated number of deaths from lung 
cancer in USA for 2017 is $155,870(84,590$ males and 71,280 females) (5). In addition to terrible human toll and emotional suffering of hundreds of thousands of families, economic burden on society is enormous. From 2000-2002 the United States spent approximately $\$ 193$ billion each year on tobacco related illnesses and lost productivity because of tobacco-related premature deaths (1). Loss in productivity and increased health care costs associated with second-hand smoking were reported in 2005 to have cost the United States an additional \$ 10 billion per year (1).

That picture looks grimmer in country like Bosnia and Hercegovina (BIH). According to Tobacco Atlas more than 8600 deaths per year are attributed to tobacco-related illnesses (6). Still, more than 2000 children (age 10-14) and 1053000 adults (15+ years old) continue to use tobacco each day. That means that $47.2 \%$ of men and $30 \%$ of women in $\mathrm{BIH}$ smoke cigarettes. That number is higher than on average in high-Human Development Index (HDI) countries. The economic cost of smoking in $\mathrm{BiH}$ amounts to 891 million KM. that includes direct cost related to healthcare expenditures and indirect costs related to loss of productivity due to early mortality and morbidity. That represents great burden on country that is still recuperating from devastating war and enormous loss of lives, most of them in full productivity age. Interesting economic facts is that tobacco growing is only small fraction of agriculture in BIH with only $0.07 \%$ of agricultural land devoted to tobacco cultivation (6). Cigarette imports exceeded cigarette exports in 2016, contributing to country's trade disbalance. It is important to register that more than $80 \%$ of 8 million tobacco-related deaths by year 2030 will be in low- and middle-income countries. Since $\mathrm{BIH}$ is part of that world, fight against cigarette smoking has to become main focus of activity of multiple levels of society.
Purpose of the paper is to present lung cancer as preventable disease through reduction in cigarette use.

\section{What to do?}

In 2003 American Society of Clinical Oncology (ASCO) released policy statement on tobacco cessation and control, which set forth specific recommendations and called for personal accountability in eradicating tobacco use domestically and globally (7). In 2013 Update (1) sets forth a refined set of recommendations for addressing tobacco cessation and control based on updated challenges and opportunities. Recommendations include: 1. Education and awareness, 2. Access to proven Tobacco Cessation Interventions, 3. Tobacco Cessation as a Component of High-Quality Cancer Care, 4, Research on Tobacco Use and Cessation, 5. US Tobacco Regulations, 6. Global Tobacco Control, 7. Leading by Example As Oncology Professionals. This Update very strongly emphasized role of physicians, particularly Oncology providers in tobacco cessation and control. Paper recommended incorporation of five A's (Ask, Asses, Assist, Advise, Arrange) of tobacco cessation in Oncology practice. Most important recommendation, in my opinion, is to ASK every patient if they are using tobacco. Without that question, other A's cannot be used. Unfortunately, in many practices in US and around the word that question is never asked. There are many reasons for that, particularly in countries where tobacco use is part of local culture and where many physicians are tobacco smokers. That raises important question of physician's education about devastating health effects of cigarette smoking. In my opinion, that is of utmost importance, particularly in countries like BIH. Oncologists have important role, since they are physicians that face and treat the most devastating effects of tobacco smoking and also deal with patients 
who are greatly motivated to stop using tobacco. Physician-relayed advice on smoking cessation increases the likelihood that patients will try to quit and enhances the odds that those who do so will remain tobacco free (1). Long-term cessation rates include $15 \%$ with counselling, $22 \%$ with medication alone and $22 \%$ to $28 \%$ when counselling in combined with pharmacotherapy (8).

Tobacco regulations are becoming very powerful tool in the curbing tobacco epidemic. In 2007 the Institute of Medicine issued a blueprint for US for ending tobacco epidemic (9). It emphasized several tobacco controlling strategies, including financial support of comprehensive state tobacco control programs at the Center for Disease Control and Prevention (CDC)-recommended levels (support for quit lines), increased tobacco taxes as a means to discourage tobacco use and stronger federal regulations and oversight of tobacco products (10). In 2009, the family Smoking Prevention and Tobacco Control Act (FSPTCA) became law, granting the Food and Drug Administration (FDA) authority to regulate the manufacture, distribution and MARKETING of tobacco products to protect public health. The FDA is tasked with aggressively restricting youth access, assessing tobacco industry research on the health and addictiveness of their products, reviewing product ingredients and additives, providing marketing orders and reviewing any health claims made by tobacco companies (11). In 2009, the US Congress voted to increase the federal tax on cigarettes via the Children's Health Insurance Program Reauthorization (12). There is substantial evidence showing that increases in the prices of tobacco products help discourage the use of such products, especially for young children, teenagers and low socioeconomic groups (13). On a global level WHO Framework Convention on Tobacco Control (FCTC) health treaty came into force in 2005 with ratification by the first 40 countries. At the present there 168 countries are signatories and 181 are parties to the WHO FCTC (14). This is comprehensive treaty, which, if effectively enforced in each country, will be deterrent to the globally growing tobacco epidemic, particularly in growing economies. In October 2011 the European Commission committed 5.2 million euros to the FCTC Secretariat to assist low- and middle-income countries to implement convention (15). However, obviously amount of money invested in this Treaty is dwarfed by marketing budget of tobacco companies. The combined revenues of the world's six largest tobacco companies in 2016 were more than $\$ 364$ billion (6). It is $1944 \%$ larger than the Gross National Income of BIH. That illustrates uphill battle against tobacco epidemics, particularly in small economies. BIH is not signatory state, but in 2009 became party to the Treaty (Accession). Despite of financial handicap, participation in the Treaty opens possibility to overcome political lobbying and commercial forces supporting tobacco use.

Which of the present best practice measures to reduce tobacco epidemics are presently used in BIH? Very few:

1. Protect from smoke. Best practice is for all public places to be completely smokefree. At the present NONE of the public places, including health care facilities, educational facilities, government facilities, restaurants, indoor offices, public transportations, and bars are smoke-free (6);

2. Raise taxes on tobacco products. At the present $\mathrm{BIH}$ is very close to WHO Benchmark (minimum $70 \%$ of retail price to be excise tax). In BIH tax is $68.67 \%$ (6). Still more can be done;

3. Offer help for tobacco cessation. Very few. There is no National Quit line. However, considering political landscape, it is more realistic to work on getting Quit lines at the Cantonal level or level of Federation and Republika Srpska; 
4. Warning labels. There is no information on percentage of packages with warning labels and there is no warning labels on plain packaging (6);

5. There is no reliable information on antitobacco campaigns, although these campaigns were proven to be very effective tool for smoking reduction. This is area where most effort should be concentrated and with involvement of physicians, educators, public, media, public relations and non-governmental organizations (NGO) results could be very significant;

6. Enforce ban on advertising. It seems there is lot to do in enforcing direct ban (TV, radio, magazines, newspapers, internet, billboards) and indirect (appearance of tobacco brands in TV and movies). Camel Joe cartoon character was banned in USA in 1997 as a part of \$ 368.5 billion settlement with tobacco producer RJ Reynold. This character was considered as attempt to target younger audience and cultivate new generation of tobacco users. It is banned from public places, TV, billboards. Same happened to Marlboro Man in 1999. It is time to retire or ban all advertising for tobacco everywhere.

At the present it is very clear that vast majority of lung cancers are directly caused by smoking. Figure 1 clearly shows almost identical shapes and parallel distribution of curves representing per capita cigarette consumption and male lung cancer death rate in USA. Lung cancer death curve lags cigarette consumption curve by 20-25 years, illustrating late effect of smoking on lung cancer formation. This confirms quoted data from SEERS showing decline in rates of cancer with decline in cigarette smoking (4). Couple of questions is always raised in discussion about causality between cigarette smoking and lung cancer.

\section{Tobacco Use in the U.S., 1900-2002}

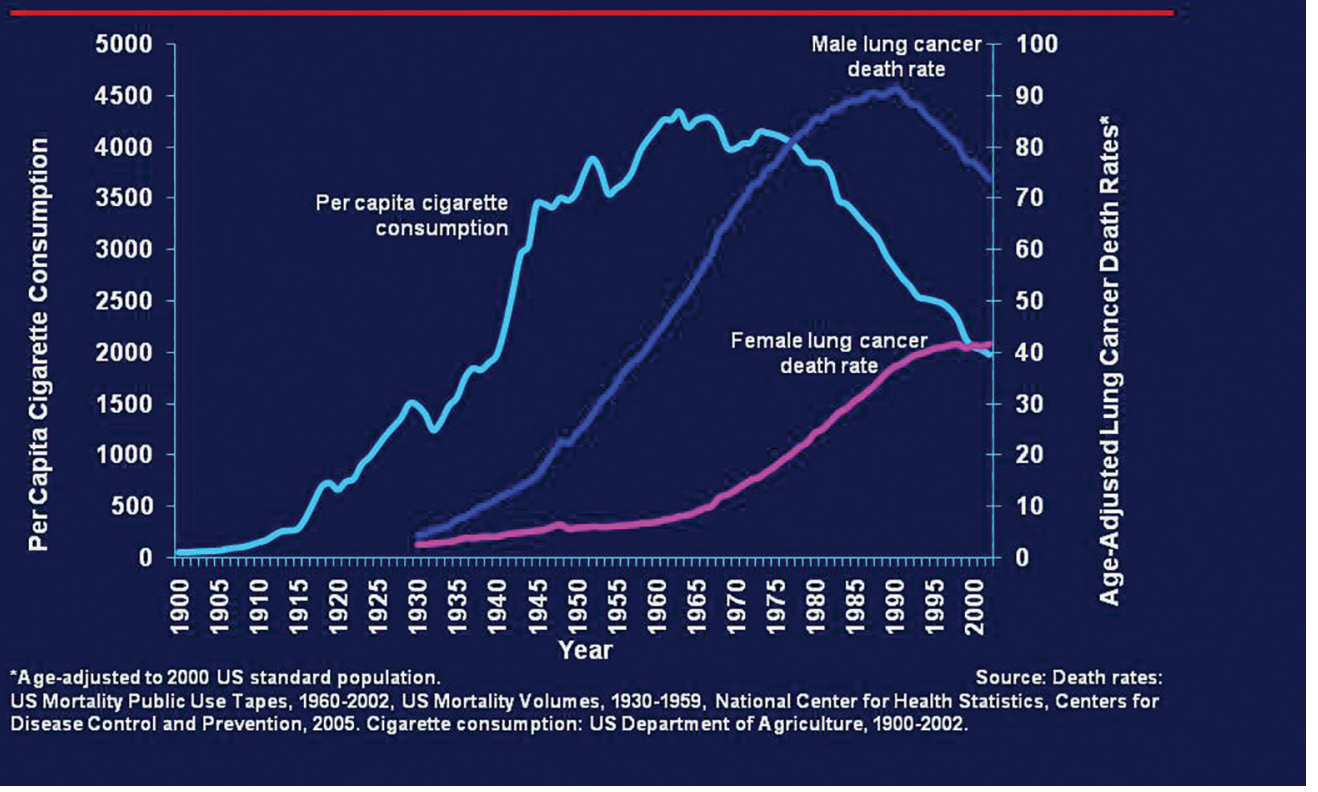

Figure 1. Tobacco use in the United States 1900-2002. 


\section{First question is: Why non-smokers get lung cancer?}

During smoking of cigarettes, cigars, pipes and other tobacco products, in addition to the mainstream smoke drawn and inhaled by smokers, a stream of smoke is released between puffs into the air from the burning cone (16). Secondhand tobacco smoke is composed of aged exhaled mainstream smoke and diluted side stream smoke. The absolute and relative quantities of many of the individual constituents of side stream smoke are different from those found in mainstream smoke. Exposure to second hand smoke can take place in any of the environments where people spend time. Some studies suggest that exposure to second hand smoke is related to occupation and socioeconomic status, and that higher exposure is more common among adults employed in blue-collar jobs, service occupations and poorly paid jobs and among less well educated (16). Exposure to second hand tobacco smoke may also be higher among racial and ethnic minorities in areas in USA, although it is unclear if this is due to different socioeconomic status (17). Because the home is predominant location for smoking, children are exposed to tobacco smoke as they go about their daily lives. The exposure at home may be added to exposure at school and in vehicles. Consequently, in many countries, children simply cannot avoid inhaling tobacco smoke (18). What are proofs that second hand smoking is associated with lung cancer? It is based on number of case-control and cohort studies. The most commonly used measure of exposure to second hand smoke has been from spouse. This is well defined and has been validated using cotinine studies of never smokers who do or do not live with smokers (16). Other measures of exposure are not so well validated. There have been eight cohort studies of nonsmokers who were followed for years to determine the risk of lung cancer. Six of these studies reported the risk of lung cancer associated with exposure to second hand smoke from spouse (16). All six studies found that the risk for nonsmoking women with partners who smoked was higher than those whose partners did not smoke. In both cohorts that reported on the effect in nonsmoking men whose wives smoked, the relative risk was increased. Many case control studies have been undertaken in several countries (mostly China and the USA). In these studies lung cancer cases were ascertained and matched with controls (usually for age and other factors). Takin the crude relative risks or the adjusted estimates when the crude ones are no available, 25 of the 40 case control studies of non-smoking women showed an increased risk (16). In total 23 studies have been published on exposure to second hand smoking at the work place. Only one study reported a statistically significant association between exposure to second hand smoke at the workplace and risk of lung cancer (19). Since all of these studies were cohorts or case-control studies, based on relatively small number of lung cancer cases and did not have enough power to generate statistical significance on their own, meta-analyses were performed with the aim of pooling the available data and providing more precise estimates of risks. Updated meta-analyses showed that among nonsmoking women who lived with a spouse who smoked, the risk of lung cancer was increased by $24 \%$ (relative risk, 1.24 ; 95\% CI, 1.14-1.3) (16). Regarding exposure at the workplace the increased risk for lung cancer in nonsmoking women is about 20\% (relatives risk 1.19; 95\% CI, 1.09-1.30). Meta-analysis identified statistically significant increase in risk among women exposed to send-hand smoke from the mother during the childhood $(50 \%$ increases in risk, but wide CI 4-114\%). There was lower and nonsignificant increase in risk for exposure to second hand smoke from the father (25\%) 
(16). Beside second hand smoking there are other occupational and environmental factors that can contribute to rise of lung cancer in relatively small, but real number of non-smokers, not exposed to second hand smoke. List is large, and we will mention only established carcinogens (inorganic arsenic, asbestos, ether, chromium compounds, gamma radiation, $\mathrm{X}$-rays, mustard gas, nickel compounds, polycyclic aromatic hydrocarbons, and radon decay products, soots, tars, mineral oils, vinyl chloride, and wood dust).

\section{Another burning question: Why only small percentages of smokers get lung cancer?}

Lung cancer is complex disease and multiple factors contribute to its raise and progression. One of the major factors is host susceptibility (20). Epidemiologic studies showing an association between family history and an increased risk of lung cancer provided the first evidence of host susceptibility. Susceptibility and risk are clearly increased in inherited cancer syndromes caused by rare germ-line mutations in p53, retinoblastoma

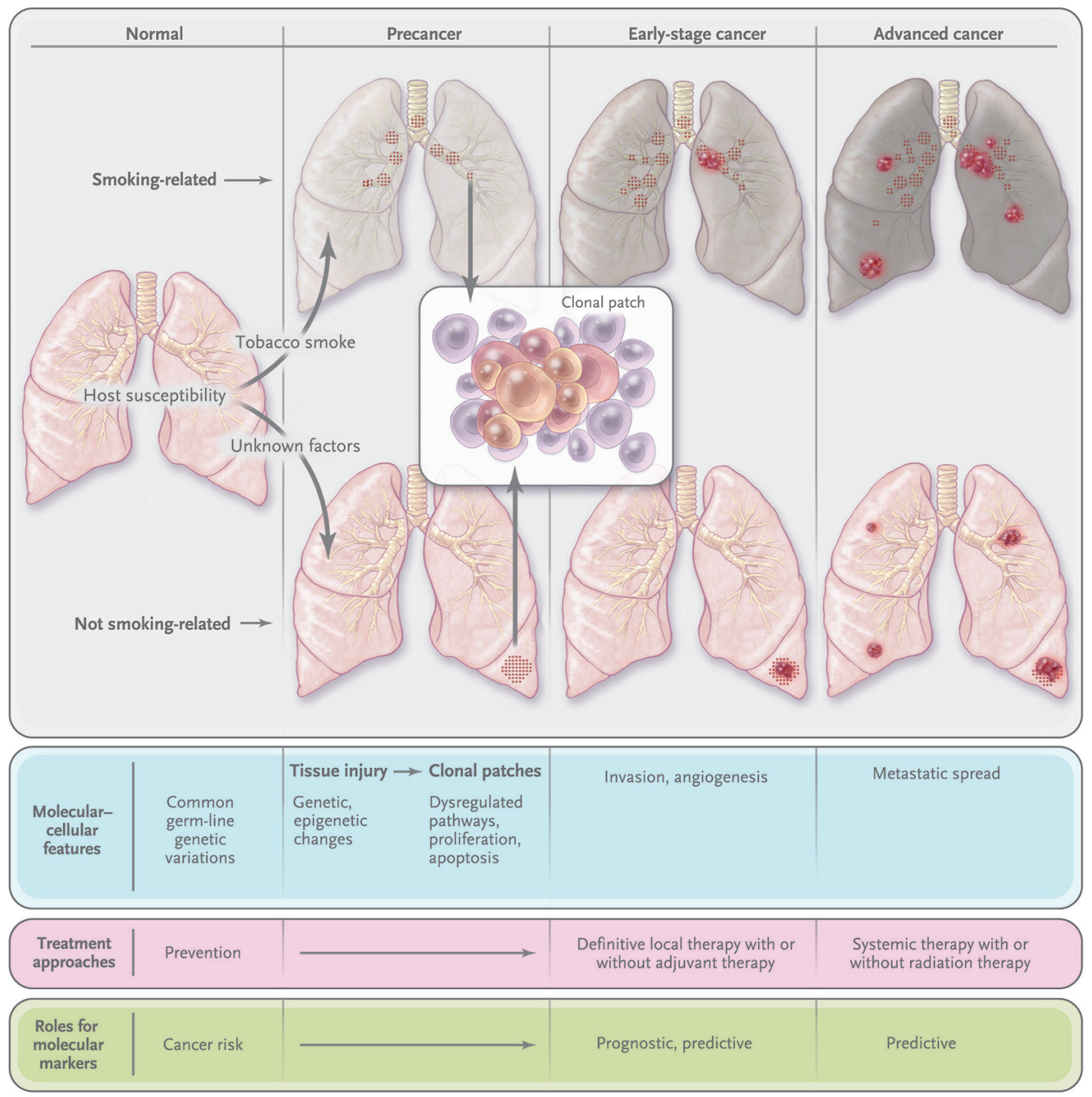

Figure 2. Molecular Evolution of Lung Cancer [Reprinted with Permission from N Engl J Med.] (20). 


\begin{tabular}{|c|c|c|c|}
\hline \multirow[t]{2}{*}{ Abnormality } & \multicolumn{2}{|r|}{ Non-Small-Cell Lung Cancer } & \multirow[t]{2}{*}{ Small-Cell Lung Cancer } \\
\hline & $\begin{array}{l}\text { Squamous-Cell } \\
\text { Carcinoma }\end{array}$ & Adenocarcinoma & \\
\hline \multicolumn{4}{|l|}{ Precursor } \\
\hline Lesion & Known (dysplasia) & Probable (atypical adenomatous hyperplasia) & Possible (neuroendocrine field) $\uparrow$ \\
\hline Genetic change & p53 mutation & $\begin{array}{l}\text { KRAS mutation (atypical adenomatous hyperplasia } \\
\text { in smokers), EGFR kinase domain mutation } \\
\text { (in nonsmokers) }\end{array}$ & Overexpression of C-MET \\
\hline \multicolumn{4}{|l|}{ Cancer } \\
\hline KRAS mutation & Very rare & 10 to $30 \%$ & Very rare \\
\hline BRAF mutation & $3 \%$ & $2 \%$ & Very rare \\
\hline \multicolumn{4}{|l|}{ EGFR } \\
\hline Kinase domain mutation & Very rare & 10 to $40 \% \div$ & Very rare \\
\hline Amplification』 & $30 \%$ & $15 \%$ & Very rare \\
\hline Variant III mutation & $5 \% 9$ & Very rare & Very rare \\
\hline \multicolumn{4}{|l|}{ HER2 } \\
\hline Kinase domain mutation & Very rare & $4 \%$ & Very rare \\
\hline Amplification & $2 \%$ & $6 \%$ & Not known \\
\hline$A L K$ fusion $\|$ & Very rare & $7 \%$ & Not known \\
\hline \multicolumn{4}{|l|}{ MET } \\
\hline Mutation & $12 \%$ & $14 \%$ & $13 \%$ \\
\hline Amplification & $21 \%$ & $20 \%$ & Not known \\
\hline TITF-1 amplification & $15 \%$ & $15 \%$ & Very rare \\
\hline p53 mutation & 60 to $70 \%$ & 50 to $70 \%$ & $75 \%$ \\
\hline LKB1 mutation & $19 \%$ & $34 \%$ & Very rare \\
\hline \multicolumn{4}{|l|}{$P \mid K 3 C A$} \\
\hline Mutation & $2 \%$ & $2 \%$ & Very rare \\
\hline Amplification & $33 \%$ & $6 \%$ & $4 \%$ \\
\hline
\end{tabular}

* Non-small-cell lung cancer includes squamous-cell carcinoma and adenocarcinoma.

$\uparrow$ Neuroendocrine fields have been detected only in tissue surrounding tumors and have been characterized by extremely high rates of allelic loss and by c-MET overexpression (Salgia R: personal communication).

$\lceil$ Variations are based in part on smoking profiles.

$\int$ The percentages include increased gene copy number from amplification or polysomy and represent percentages from resected cancers.

The percentages are higher in primary tumors from patients in whom metastatic disease develops. Increased copy numbers have been reported in squamous dysplastic lesions but not in adenocarcinoma precursors.

I Genomic EGFR variant III mutations have been detected only in lung squamous-cell carcinoma, and these tumors are sensitive to irreversible EGFR tyrosine kinase inhibitors. The incidence of $5 \%$ is substantially lower than that of 30 to $40 \%$ for the detection in squamous-cell carcinoma or adenocarcinoma by immunohistochemical analysis or other techniques.

$\|$ The anaplastic lymphoma kinase ( $A L K)$ fusion gene (involving chromosome $2 \mathrm{p}$ ), consisting of parts of $E M L 4$ and $A L K$, is transforming in fibroblasts and occurs in adenocarcinoma but not in other types of non-small-cell lung cancer or other nonlung cancers.

Table 1=Reprinted from permission from N Engl J Med. (20).

and other genes, as well as germ-line mutations in the epidermal growth factors receptor (EGFR) gene (21-24). More recently, three large genome wide association studies identified an association between singlenucleotide polymorphism (SNP) variation at $15 \mathrm{q} 24-15 \mathrm{q} 25.1$ and susceptibility to lung cancer (20). The region of the SNP variation was linked to lung carcinogenesis and includes 2 genes encoding subunits of the nicotinic acetylcholine receptor alpha, which is regulated by nicotine exposure (25, 26). Lung cancer susceptibility and risk also increase with reduced DNA repair capacity (particularly when accompanied by exposure to tobacco smoke) that results from germ-line alterations in nucleotide excision repair genes, such as ERCC1 $(27,28)$. An- 
other contributing factor to the rise of lung cancer is clonal evolution. Changes in certain genes occur in both nonmalignant lung tissue of smokers and patients with lung cancer pointing to diffuse lung injury (20). This is consistent with theory of "field carcinogenesis" or "field cancerization" (29). Molecular evolution of the lung cancer is presented in Figure 2.

Early events in the development of nonsmall-cell lung cancer include loss of heterozygosity $(\mathrm{LOH})$ at chromosomal region 3p21.3, 3p14.2, 9p21 (p16) and 17p13 (p53). All these genes are tumor-suppressor genes. LOH patterns in squamous cell and adenocarcinoma differ (chromosome 3p deletion is much more extensive in squamous cell carcinoma) (20). Mutations in the EGFR kinase domain occur early in the development of adenocarcinoma that is generally unrelated to smoking, and KRAS mutations occur early in the development of smoking related adenocarcinoma $(30,31)$. Genetic abnormalities specific in lung cancers are presented in Table 1. In addition to these abnormalities, chromosomal rearrangement of the gene encoding ROS1 protooncogene receptor kinase was found to define a distinct molecular subgroup of non small cell lung cancers (32).

\section{What influence genetic abnormalities related to lung cancer have on oncology practice?}

There is a sea of change in how we approach lung cancer in every day's practice. Recently, treatment paradigms for non-small cell lung (NSCLC) which account for $80-85 \%$ of all lung cancers have shifted from one based on histology (adeno-, squamous- and large-cell carcinoma) to one that incorporates molecular subtypes involving particular genetic alterations that drive and maintain tumorigenesis (33). Story started with identification of somatic mutations in the tyrosine kinase domain of the EGFR gene in $8 / 9$ patients who responded to tyrosine kinase inhibitor (TKI) gefitinib, while none of the 7 patient who did not have mutation showed response (34). Subsequently it was found that mutations in the EGFR most commonly deletions in exon 19 affecting the amino acid motif LREA (delE476-750) or substitution of arginine for leucine at position 858(L858R) in exon 21 are present in approximately $17 \%$ of tumors in patients with pulmonary adenocarcinoma and lead to constitutive activation of EGFR tyrosine kinase (35). The mutations occur with increased frequency in women and nonsmokers. Responses to EGFR TKI's in patient carrying these activating mutations were much higher (78\%) than what has been described in patients treated with standard platinum -doublet chemotherapy (25-30\%). The vast majority of patients who have an initial response to EGFR TKI's will eventually relapse. Recent studies identified EGFR T790M mutations (in exon 20) as a main culprit for lack of response or relapse in patients with EGFR gene mutations after treatment with standard EGFR TKI's . The binding kinetics of the mutant EGFR appears to be altered by the T790M mutation (20). New irreversible EGFR inhibitors suppress T790M-mutatnt tumor cells are showing now to be effective treatment for patients carrying that specific mutation. Other activating mutation that has major effect on biology and lung cancer progression is KRAS mutation which limited to NSCLC, predominantly adenocarcinoma and is virtually mutually exclusive of mutations in EGFR kinase domains and is associated with resistance to EGFR TKI's and chemotherapy. Most KRAS mutations are smoking-related $\mathrm{G}$ to $\mathrm{T}$ transversions and affect exon 12 (90\% of patients) and exon 13 (36). A distinct KRAS mutational profile consisting of $\mathrm{G}$ to $\mathrm{A}$ transition mutation was recently detected in non-smokers and is on unclear functional significance (20). Transversions 
(smokers) and transitions (non-smokers) also have been reported for p53 mutations in lung adenocarcinomas (36). Activating mutations or translocations of the anaplastic lymphoma kinase gene (ALK) have been identified in NSCLC by Japanese group (37). In NSCLC EML4-ALK is an aberrant fusion gene that encodes a cytoplasmatic chimeric protein with constitutive kinase activity (36). Multiple distinct EML4-ALK chimeric variants have been identified, representing breakpoints within various EML4 exons. This genetic mutation is not common occurring in $2-7 \%$ of all NSCLC and is more prevalent in patients who never smoked or who have history of light (short period and small number of cigarettes) smoking (38). However considering very high incidence and prevalence of lung cancer, we can estimate that 7,800 patients in USA and 60,000 worldwide will every year be diagnosed with EML4-ALK positive NSCLC. That particularly becomes important in the light of very effective treatments with first, second and now third line selective ALK inhibitors. It is interesting that first generation ALK inhibitor crizotinib showed great efficacy in patients with ROS1-rearranged NSCLCA (39). The ROS1 oncogene encodes an orphan receptor tyrosine kinase related to ALK, along the members of the insulin receptors family. ROS1 is activated by chromosomal rearrangement in variety of human cancer including NSCLC. Rearrangement leads to fusion of a portion of ROS1that includes the entire tyrosine kinase domain with 1 of 12 different partner proteins (39). The resulting ROS1 fusion kinases are constitutively activated and drive cellular transformation and proliferation. ROS1 rearrangement occur in approximately $1 \%$ of patients with NSCLC and approximately 1,300 in US and 15,000 worldwide cases will be driven by oncogenic ROS1 fusion. It is again more frequently found in non-smokers and patient with history of light (short period and small number of cigarettes) smoking. Another mutation that could be important in the treatment of NSCLC is mutation in B-Raf proto-oncogene, serine/threonine kinase (BRAF). Mutations in BRAF, observed in $2 \%-4 \%$ of NSCLCs, typically lead to constitutive activation of the protein and, as a consequence, lead to activation of the mitogenactivated protein kinase signaling pathway. Direct inhibition of mutant BRAF and/or the downstream mitogen-activated protein kinase (MEK) has led to prolonged survival in patients with $B R A F$-mutant metastatic melanoma (40). Same treatment is showing promise in the treatment of patients with NSCLC.

\section{Conclusion}

In conclusion lung cancer is very heterogeneous disease with high tumor mutational burden and very hard to treat when metastatic. However, it is preventable disease in very high percentage of cases (85-90\%). Goal is to exterminate cigarette smoking. That can be achieved only concerted effort by members of family, patients themselves, physicians, researchers, non-governmental organizations, political figures and society as whole. Best practices already exist and initial goal should be to start using them. BIH society needs to make steps toward adopting all these strategies. Otherwise, cost in human life will continue to grow.

Acknowledgements: Appreciate assistance by Harsha Trivedi $\mathrm{PhD}, \mathrm{RN}$ in preparation of this paper.

Conflict of interest: The author declares that he has no conflict of interest.

\section{References}

1. Hanna N, Mulshine J, Wollins DS, Tyne C, Dresler C. Tobacco Cessation and Control a Decade Later: American Society of Clinical Oncology Policy Statement Update. J Clin Oncol. 2013;31(25):3147-57. 
2. Wynder EL, Graham EA. Tobacco Smoking as a Possible Etiologic Factor in Bronchiogenic Carcinoma; A Study of Six Hundred and Eighty-Four Proved Cases. J Am Med Assoc. 1950;143(4):32936.

3. Doll R, Hill AB. Smoking and Carcinoma of the Lung. Br Med J. 1950; 2(4682):739-48.

4. Office of the Surgeon General (US); Office on Smoking and Health (US). The Health Consequences of Smoking: A Report of the Surgeon General. Atlanta (GA): Centers for Disease Control and Prevention (US); 2004. p. 39-61.

5. Siegel RL, Miller KD, Jemal A. Cancer Statistics, 2017. CA Cancer J Clin. 2017;67(1):7-30.

6. Tobaccoatlas.org Prevalence. [cited April, 11, 2018] Available from: https://tobaccoatlas.org/ topic/prevalence.

7. American Society of Clinical Oncology. American Society of Clinical Oncology policy statement update: Tobacco control - Reducing cancer incidence and saving lives. J Clin Oncol. 2003;21(14):277786.

8. Fiore MC, Jaén CR, Baker TB, Bailey WC, Benowitz NL, Curry S, et al. Treating Tobacco Use and Dependence: 2008 Update. Clinical Practice Guideline. Rockville: U.S. Department of Health and Human Services; 2008.

9. Tobacco Use and Dependence Guideline Panel. Treating Tobacco Use and Dependence: 2008 Update. Rockville, MD: US Department of Health and Human Services; 2008.

10. Bonnie RJ, Stratton K, Wallace R, editors. Ending the Tobacco Problem: A Blueprint for the Nation. Washington DC: National Academic Press; 2007.

11. Pub Law 111-31. Family Smoking Prevention and Tobacco Control Act 2009. [cited 2018 Apr 11]. Available from: http://gpo.gov/fdsys/pkg/PLAW111publ31/html/PLAW-111publ31.htm.

12. Pub Law 111-3. Children's Health Insurance Program Reauthorization Act of 2009. [cited 2018 Apr 11] Available from: http://www.gpo.gov/fdsys/pkg/PLAW-111publ/html/PLAW-111publ3. htm.

13. Chaloupka FJ. Macro-social influences: The effects of prices and tobacco-control policies on the demand for tobacco products. Nicotine Tob Res. 1999;1(Suppl 1):S105-9.

14. World Health Organization. Framework convention on tobacco control. Geneva (Switzerland): World Health Organization; 2005. [cited 2018 Apr 11].Available from: http://www.who.int/fctc/en/.

15. European Commission. European commission provides 5.2 million euros to help lower income countries in tobacco control. [cited 2018 Apr 11].
Available from: http://ec.europa.eu/health/tobacco/docs/announcement_260911_en.pdf.

16. International Agency for Research on Cancer. IARC Monographs on the Evaluation of Carcinogenic Risks to Humans, No. 83. Lyon, France: International Agency for Research on Cancer; 2004.

17. Gerlach KK, Shoplan DR, Hartman AM, Gibson JT, Pechacek TF. Workplace smoking policies in the United States: results from a national survey of more than 100,000 workers. 1997;6(3):199-206.

18. Samet J, Yang G. Passive smoking, women and children. In: Samet J, Yoon S-Y, editors. Women and the Tobacco Epidemic, Challenges for the 21st Century. Geneva: World Health Organization; 2001. p. 17-48.

19. Reynolds P, Von Behren J, Fontham ETH, Wu A, Buffler P, Greenberg R. Occupational exposure to environmental tobacco smoke. J Am Med Assoc. 1996;275(6):441-2.

20. Herbst RS, Heymach JV, Lippman SM. Molecular Origins of Cancer: Lung Cancer. N Engl J Med. 2008;359(13):1367-80.

21. Hwang SJ, Cheng LS, Lozano G, Amos CI, Gu $\mathrm{X}$, Strong LC. Lung cancer risk in germline p53 mutation carriers: association between an inherited cancer predisposition, cigarette smoking, and cancer risk. Hum Genet. 2003;113(3):238-43.

22. Sanders BM, Jay M, Draper GJ, Roberts EM. Nonocular cancer in relatives of retinoblastoma patients. Br J Cancer. 1989;60(3):358-65.

23. Bailey-Wilson JE, Amos CI, Pinney SM, Petersen GM, de Andrade M, Wiest JS, et al. A major lung cancer susceptibility locus maps to chromosome 6q23-25. Am J Hum Genet. 2004;75(3):460-74.

24. Bell DW, Gore I, Okimoto RA, Godin-Heymann N, Sordella R, Muloy R, et al. Inherited susceptibility to lung cancer may be associated with T790M drug resistance mutation in EGFR. Nat Genet. 2005;37(12):1315-6.

25. Hung RJ, McKay JK, Gaborieau V, Boffetta P, Hashibe M, Zaridze D, et al. A susceptibility locus for lung cancer maps to nicotinic acetylcholine receptor subunit genes on $15 q 25$. Nature. 2008;452(7187):633-7.

26. Lam DC, Girard L, Ramirez R, Chau WS, Suen WS, Sheridan S, et al. Expression of nicotinic acetylcholine receptor subunit genes in non-small-cell lung cancer reveals differences between smokers and nonsmokers. Cancer Res. 2007;67(10):463847.

27. Spitz MR, Wei Q, Dong Q, Amos CI, Wu X. Genetic susceptibility to lung cancer: the role of DNA damage and repair. Cancer Epidemiol Biomarkers Prev. 2003;12(8):689-9. 
28. Yu D, Zhang X, Liu J, Yuan P, Tan W, Guo Y, et al. Characterization of functional excision repair cross-complementation group 1 variants and their association with lung cancer risk and prognosis. Clin Cancer Res. 2008;14(9):1878-2886.

29. Dokubo GD. Danely P. Slaughter's Field Cancerization Concept of Carcinogenesis: The Path Forward to Early Cancer Detection and Chemoprevention. Cell Devel Bio. 2015;4(2):158.

30. Westra WH. Early glandular neoplasia of the lung. Respir Res. 2000;1(3):163-9.

31. Tang X, Shigematsu H, Bekele BN, Roth JA, Minna JD, Hong WK, et al. EGFR tyrosine kinase domain mutations are detected in histologically normal respiratory epithelium in lung cancer patients. Cancer Res. 2005;65(17):7568-72.

32. Gold KA. ROS1- Targeting the One Percent of Lung Cancers. N Engl J Med. 2014;371(21):2030-1.

33. Pao W, Hutchinson KE. Chipping away at the lung cancer genome. Nature. 2012;18(3):349-51.

34. Lynch TJ, Daphne BW, Sordella R, Gurubhagavatula S, Okimoto R, Brannigan BW, et al. Activating Mutations in the Epidermal Growth Factor Receptor Underlying Responsiveness of Non-SmallCell Lung Cancer to Gefitinib. N Engl J Med. 2004;350(21):2129-39.
35. Roseli R, Moran T, Queralt C, Porta R, Cardenal F, Camps C, et al. Spanish Lung Cancer Group. Screening for epidermal growth factor receptor mutations in lung cancer. N Engl J Med. 2009;361(10):958-67.

36. Sun S, Schiller JH, Gazdar AF. Lung cancer in never smokes - a different disease. Nat Rev Cancer. 2007;7:778-90.

37. Soda M, Choi YL, Enomot, Takada S, Yamashita Y, Ishikawa $\mathrm{S}$, et al. Identification of the transforming EML4-ALK fusion gene in non-small-cell lung cancer. 2007;44(7153):561-6.

38. Kwak EL, Bang Y, Camidge R, Shaw A, Solomon B, Maki RG, et al. Anaplastic Lymphoma Kinase Inhibition in Non-Small-Cell Lung Cancer. N Engl J Med. 2010;363(18):1693-703.

39. Shaw AT, Ou S, Bang Y, Camidge R, Solomon BJ, Salgia R, et al. Crizotinib in R0S1-Rearranged Non-Small-Cell Lung Cancer. N Engl J Med. 2014;371(21):1963-71.

40. Balk CS, Myall NJ, Wakelee HA. Targeting BRAFMutant Non-Small Cell Lung Cancer: From Molecular Profiling to Rationally Designed Therapy. Oncologist. 2017;22(7):786-96. 